\title{
The Church of the Holy Sepulchre during the Time of Constantine the Great: The Question of the Golgotha
}

\author{
Elena Lavrentyeva \\ The State Institute for Art Studies \\ Moscow, Russia \\ lavrentyeva27@gmail.com
}

\begin{abstract}
The rock of Golgotha is situated inside the Church of the Holy Sepulchre. The Church itself hasn't kept the initial design (4th c.) by reason of the earthquakes, fires or invasions. After 614, there was no century without demolishing. There are different assumptions concerning history of its construction. The aim of the article is systematization of various scholars' opinions of the architectural design of Golgotha during the reign of Constantine the Great. It is consistently shown the use of different study methods caused a divergence of researchers' opinions.
\end{abstract}

Keywords-Church of the Holy Sepulchre; Golgotha; Calvary; "the Place of a Skull"; "the Middle of the World"; Garden Tomb (Gordon's Calvary); Jerusalem

\section{INTRODUCTION}

The Church of the Holy Sepulchre stands in the place of the abandoned stone quarry which was filled up in the 1st century BC. The foundation of its western part is carved into the rock around the Holy Sepulcher (in European literature "Rotunda Anastasis"); the eastern part of the temple stands on the rock and the foundations of earlier buildings (in the research literature - the catholicon). Golgotha - rocky ledge - is under its arches. The temple has undergone much destruction from fires and raids; that is why it does not correspond to its original appearance of the 4th century. There are various assumptions concerning the history of its construction.

Nowadays, it remains unclear whether the Church of the Holy Sepulcher has remained the same building for centuries, or, on the contrary, it is represented by several buildings (the church was destroyed and a new one was erected in its place). Its architectural appearance always attracted the researchers' attention, but the appearance of scientific interest in its original appearance and construction history was affected by the fire of 1808 , which destroyed almost $2 / 3$ of the building.

\section{SOME QUESTIONS OF THE RECONSTRUCTION OF THE CHURCH OF HOLY SEPULCHRE}

During the first half of the 19th century, researchers began to create different versions of the original appearance of the shrine. A hypothesis was proposed, according to which the modern Church of the Resurrection preserved the structure created in the 4th century (A.K.A. Zestermann,
1841; R. Willis, 1844; M. de Vogüé, 1859; I.N. Sepp, 1862 S. Warren and K. Conder, 1884, archimandrite Leonid, 1885 P. Mansurov, 1888, T. Hanter-Lewis, 1888, K. Mommert, 1898). Following this assumption, the authors agreed that the building was still fragmented, undergoing changes (almost uncountable number of restoration works were carried out in the temple from the 7th century on), but, even with numerous restoration "patches", the originally conceived appearance of the Church of the Anastasis has survived to the present day.

At the beginning of the second half of the 19th century, an opposite hypothesis was proposed, asserting that the structure and appearance of the 4th century church was very different from the modern one (T. Tobler, 1851, Bock, 1850s, P. Schegg, 1867, I.S. Sepp and B. Sepp, 1882; C. Schick, 1885; J. Jeffery, 1885; M. Closs, 1898, J. Germer-Durand, 1898). There is one important clarification in this hypothesis: The Church was rebuilt partially. That part of it, in which the Holy Tomb was, didn't change (the reason of the appearance of the term "Rotunda Anastasis"). Based on the pilgrimage descriptions of the shrine, the surviving church images and its schemes, it is believed that the two-story colonnade, located around the Aedicule and carrying the weight of the dome, was planned by Constantine the Great (or his architects). It is believed that the modern interior of Anastasis corresponds to what it was during the 4th century. According to the second hypothesis, while the western part of the Church of the Resurrection was carefully preserved for centuries, its eastern part was constantly rebuilt.

Also, M. de Vogüé proposed a theory of building phases of the Church of the Holy Sepulchre. He suggested that it was rebuilt 3 times: in the 4th century, it was built by Constantine the Great. In the 7th century, it was restored with the changes by the Patriarch of Jerusalem Modestus. In the 11th century - by Byzantine emperors Romanos III Argyros, Michael IV the Paphlagonian and in the 12th century - by the Latin kings. The assumption that the building was erected several times was put forward by de Vogüé for a number of reasons. First, from written sources, it is known that it was destroyed "to the ground" during the Persian invasion in 614 and by order of the caliph al-Hakim in 1008 (9). It is also known that a large-scale restoration work was carried out under the auspices of Crusader kings because the Church of the Holy Sepulchre was chosen as the 
place of coronation. Secondly, according to medieval plans (plan of Arculf (about 670), etc.), the church configuration after its first restoration in 617 didn't reproduce Constantine's building. There was a round edifice within the Holy Tomb inside in the center; Golgotha and other shrines were fenced with a wall from the city. Third, the walls of the restored Church of the Holy Sepulcher of the 19th century contained stone blocks of different epochs, as well as sculptural and mosaic decorations indicated several stages of construction.

Subsequently, L.-H. Vincent (1914) adopted de Vogüé's theory and combined it with the second hypothesis (the initial Church of the Resurrection was a complex of buildings), although de Vogüe himself held the opposite point of view according to which Golgotha and the Holy Tomb were inside unified church space during 4th century. Also, Vincent refused to single out the restoration of the shrine in 7 th century as a separate stage and made a small correction to the plan reconstruction of the 11th century.

Rejection of the first stage of the restoration in 617 proposed by de Voguié caused the problem of the reconstruction of the basilica of Martirium. According to the version of Vincent, the temple of the Resurrection erected in the era of Constantine was destroyed in 614, but, since there was almost no archaeological evidence on which one could get an idea of the restored church of the 7th century, he suggested that the patriarch Modest didn't change the structure of the complex. D. Pringle followed this version and marked on the plan of the 11th century ruins of Martirium, suggesting that the basilica was destroyed in 1008 (9) by the order of Caliph Al-Hakim.

According to the theory of de Vogüe, Martirium was erected in 4th century, and it wasn't a separate basilica but the eastern part of the Church of the Resurrection where Golgotha was originally located. Presumably, Persians destroyed it, and Modest didn't restored. Nevertheless, the space to the east of the Holy Tomb was still sacred. Nowadays, the middle of the earth is located here, and, from the north and south, it was fenced with a wall. Also, Patriarch Modestus built a chapel over Golgotha. The assumption that Martirium existed from the 4th to the beginning of the 11th century remains controversial.

Modern scholars' reasoning about the history of the Church of the Resurrection is based on the second hypothesis (one type of the building was changed to another type provided that the western part was preserved). The opposite and first hypothesis (about preservation of the structure through the centuries) was abandoned; the last work in which this idea was followed was the book of K. Mommert (1898). The theory of de Vogüe (1859) also underwent significant changes, and his assumption of the four construction stages was replaced with Vincent's statement of the three stages (4, 11, 12 centuries), followed by Ch. Coüasnon and V.C. Corbo.

There is the question about Golgotha in 4th century. Its reconstruction was assumed by scholars depended on one of two hypotheses. Was it inside the Church of the Holy Sepulchre (by analogy with its modern position) or outside the walls of the Church? The researchers offered different options.

\section{THE GOLGOTHA}

Now in the Church of the Resurrection, Golgotha can be seen from several positions: being in front of the altar of the crucifixion; in the chapel of Adam, where in the wall of the apse a small square window is carved in which a crack in the rock is visible; and in the space between the chapel of Adam and the main apse of the Church, looking to the east. Directly on top of the rock is the altar of the crucifixion. Before the restoration between 1809-1810, it was located above aperture of the Crucifixion (round in shape and depth of about $40 \mathrm{~cm}$ ). During the fire of 1808 , the chapel of Golgotha suffered very much, and, in order to protect the holy place from further destruction, it was decided to move the altar closer to the entrance, to the west [1]. The modern altar is signified with silver disc through which one can touch the rock with his palm, but the place of the Crucifixion is at some distance from it.

At the foot of the Golgotha rock, there is a chapel of Adam, the altar of which is located strictly under the altar of the Crucifixion. There are two entrances to it: opposite to the altar and from the north. In the apse wall, there is a small window through which faithful can see a crack in the rock, which refers to Matthew's words: "The earth shook, the rocks split" (Mt 27:51). Here in the chapel of Adam, there are the burials of the Latin kings on both sides of the western entrance (Godefroy of Bouillon (d. 1100), Baldwin I (d. 1118), Baldwin II (d. 1131), Fulk of Anjou (d. 1143), Baldwin III (d. 1163), Amaury I (d. 1174), Baldwin IV (d. 1185), and Baldwin V (d. 1186)). Their original location was different: eight tombs were in the southern space of the Church near the stone of crismation (the first thing that pilgrims see at the entrance to the Church of the Resurrection). After the fire of 1808 , the remains were reburied in the chapel of Adam (Pringle 2007: 37;

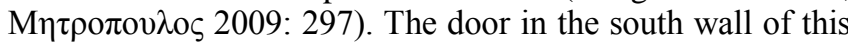
chapel leads to the treasury of the Church of the Holy Sepulcher.

During the two-hundred-year period of study of the Church of the Holy Sepulchre, there were created circa 20 reconstructions of the plan of the 4th century building. Moreover, Golgotha is not even mentioned in 9 plans. Also, researchers turned to written sources of pilgrims. One of the most important was "Vita Constantini" of Eusebius Pamphili (c. 337), "Itinerarium Egeriae" (about 384), "Breviarius de Hierosolyma" (about 530), etc. In the 20th century, ancient descriptions of the Holy Land were supplemented by archaeological material obtained during the excavations.

\section{THE RECONSTRUCTIONS OF GOLGOTHA (4TH CENTURY)}

Researchers, who assumed Golgotha was located inside the Church of the Resurrection and where the Holy Tomb was also located (first hypothesis), conditionally divided the space of the building into two unequal zones: the church of the resurrection in the west and the basilica Martitium in the 
east. Golgotha was placed in the Martirium (de Vogüé, arch. Leonid, Mansurov, Mommert). In their opinion, except Mommert, the size of the church corresponded to modern ones. And Mommert believed the Constantine's Church of the Holy Sepulchre was almost twice as large as present one.

Some other reconstructions of the 19th century (second hypothesis) represent the Golgotha in the courtyard near basilica Martirium: on the Jeffery plan, the rock was in the center of the courtyard. On the Schegg's plan and also Germer-Duran's plan, it was in the south-eastern corner of the courtyard. The same point of view was followed by D.V. Ainalov, who wrote that originally Golgotha - "a natural rock or a hill with a cross over it" - "stood outdoors in the atrium between the Church of the Resurrection and the Basilica of Constantine (Martirium)" [2].

J. Strzygowski was also interested by question of the Holy Sepulchre reconstruction. In his book "Orient oder Rom", he dedicated a chapter to the Church of the Anastasis during epoch of Constantin the Great [3]. Discussing with Ainalov, he suggested the Golgotha was behind the "ancient two-tiered atrium", which was decorated with lamps already in the time of Egeria (Strzygowski, 1901) [4] [5]. The Capella Franca, named by Strzygowski "den kleinen Vorbau", was defined as a late external entrance to Golgotha until the restoration work of the early 16 th century [6].

On Strzygowski's argument, Ainalov commented in form of glosses written in the margins of the book "Orient oder Rom" (published by L.G. Khrushkova). According to Strzygowski's reconstruction, Golgotha, with the Cross on the top, was inside the basilica and in the south-western corner. Ainalov made a note with an objection: "This is not in any case. If so, the Cross on Calvary was inside the basilica?" (trans. from Russian). One more gloss of Ainalov objecting to Strzygowski's position again. He assumed the southern wall of basilica Martirium couldn't be erected on that place where nowadays walled second door of the Church of the Holy Sepulchre is located [7]. However, it is unlikely that the top of the rock was roughly constrained for the reason to be included into the basilica as D. Pringle rightly notes [8]. Conversely, the desire to preserve Golgotha in its original form suggests the primacy of the shrine appearance over the architectural structure.

In the plan-reconstruction made by Vincent, Golgotha was in the south-eastern part of the courtyard, and it was combined by additional architectural construction with the southern nave of the basilica of Martirion [9]. In the crosssection of the Church complex (the same plate), Golgotha was not depicted at all, the courtyard was represented by a number of columns which, in the east, ended with the apse of the basilica of Constantine, indicating the theoretical nature of the reconstruction proposed by the author.

Two construction stages of the Church of the Holy Sepulcher during the 4th century were proposed by $\mathrm{Ch}$. Coüasnon in his monograph published on the basis of archaeological research [10]. The first stage showed the Aedicule within the Holy Tomb in the open air, and the second one was the Aedicule already under the dome of Anastasis [11] [12]. In both reconstructions, the rock of
Calvary was shown as a four-story church crowned by a small dome. To the west of Golgotha, a narrow southern atrium was located. According to the author's opinion, the church of Golgotha had no communication with Martirium; it was an independent architectural structure, erected above the site of the Crucifixion. To the east of Calvary, there is a sheer wall preserved from the southern nave of Martirirum which according to Corbo and Katsimbinis was carved out from the same rock formation [13] [14].

V.C. Corbo suggested that, in the 4th century, Golgotha was incorporated to the southeast corner of the courtyard named "triportico". There was no adjacency between the rock and the wall of the basilica southern nave [15]. Between Golgotha and the place where Martirium was erected, there was a shallow quarry (depth $-6.75 \mathrm{~m}$ ) which, according to Coüasnon in the 1 st century $\mathrm{BC}$, was filled to a level that was just below the modern level of the floor in the Adam chapel. The height of the rock was equal to $4.20 \mathrm{~m}$ [16]. In this area above the fill (i.e. east of Golgotha), there was a simple staircase that led to the third tier where the altar of Melchizedek located above the chapels of Adam and Golgotha. During the restoration of the 1970s, it was replaced by a spiral staircase. The room where it begins is on the same tier with the altar of Crucifixion and is reserved for daily living needs where the holy vessels are stored (candlesticks, candles, carpets, etc.), but only priests can enter this room. Also, in the eastern slope of Golgotha at the level of the chapel of Adam, a small niche was cut out (the time of creation is unknown) which apparently served as an altar place.

The assumption that Golgotha was inside the atrium was supported by F. Mitropoulos. The rock stood isolated under the open sky with the Cross on the top (not like Schegg or Coüasnon thought that Golgotha was inside the porticoconstruction) [17]. He also suggested the construction appearance above Calvary in 5th and 7th centuries. His position is consistent with the words of Ainalov, who wrote that after the Persian invasion in 614 when Martyrium and the Church of the Resurrection was strongly damaged, "a small church was erected over the rock with a cross which the pilgrims of the 7th and 8th centuries called the "Ecclesia Golgothana" [18]. Corbo found out that the four pillars supporting the pointed arch above Golgotha were erected soon after the destruction of the shrine in 614. During the 11 th century between two eastern pillars, a wall was erected and preserved till nowadays. Moreover, the medieval construction of 11 th century southern wall was also preserved. As Coüasnon believed, the chapel of Melchisedech escaped destruction by Caliph Al-Hakim and was incorporated to the upper tier. Consequently, the chapel before 1008 (9) was already three-tiered: the chapel of Adam, the chapel of the Crucifixion and the chapel of Melchisedech. It could be built in three stories already in the 7 th century when it was a separate structure. In the 12th century, Golgotha was integrated into the space of the Crusader Church of the Holy Sepulchre. 


\section{CONCLUSION}

Considering the plan-reconstructions of the Church of the Resurrection where Calvary is marked, one can distinguish four main types of Golgotha reconstruction. According to the first one, it was inside the main Church (de Vogüe), like a modern location; the second one - the Golgotha was in the south-western corner of the basilica Martirium (Strzygowski); the third - in the southeast corner of the triportico as a separate church (Coüasnon, Corbo); and the fourth - a

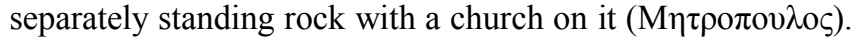
There is no answer to which position is right or highly close to it. The question of the reconstruction of Calvary requires further consideration. It remains to be seen whether Calvary was inside the church structure or whether it stood in the open air (in the last case inside the atrium of church complex).

\section{REFERENCES}

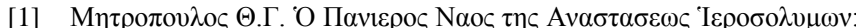

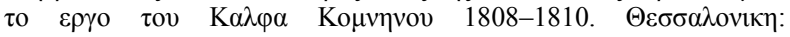

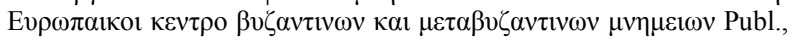
2009, p. 298.

[2] D.V. Ainalov, Vizantiiskie pamiatniki Afona (Byzantine monuments of Athos). Vizantiiskii Vremennik (Byzantina Xponika), 1899, vol. VI, no. 1-2, p. 66.

[3] J. Strzygowski, Orient oder Rom. Beiträge zur geschichte der spätantiken und frühchristlichen kunst. Leipzig: J.C. Hinrichs'sche Buchhandlung Publ., 1901, pp. 127-150.

[4] D.V. Ainalov, Byzantine monuments of Athos, Byzantina Xponika, 1899, vol. VI, No. 1-2, pp. 63-72 (in Russian).

[5] J. Strzygowski.

[6] L.A. Beliaev, The Capella Franca in New Jerusalem? Architectural and archaeological objects at the southern façade of the Resurrection Cathedral (preliminary research). Architectural Heritage, vol. 65, ed. I.A. Bondarenko, Moscow; Saint Petersburg: Kolo Publ., 2016, p. 70.

[7] L.G., Josef Strzygowski and Joseph Wilpert in Russia: ideas, discussions, cooperation. Byzantium in the context of world culture, (ed.) V.N. Zalesskaia. Saint-Petersburg: State Hermitage Publ., 2013, pp. 550, 552-553.

[8] D. Pringle, The churches of the Crusader Kingdom of Jerusalem, vol. III: The city of Jerusalem. New York, Cambridge: Cambridge University Press Publ., 2007, p. 7.

[9] L.-H Vincent, F.-M Abel, Jérusalem, Recherches de topographie, d'archéologie et d'histoire. Tome second: Jérusalem nouvelle. Fascicule I et II: Aelia Capitolina - Le Saint-Sépulcre - Les sanctuaires du mont des Oliviers. Paris: J. Gabalda et Compagnie Publ., 1914, pl. XXXIII.

[10] Ch. Coüasnon, The Church of the Holy Sepulchre in Jerusalem. London: Oxford University Press Publ., 1974, pp. 50-53.

[11] Ch. Coüasnon, pl. VII.

[12] Coüasnon Ch., pl. XVII.

[13] V.C. Corbo, Il Santo Sepolcro di Gerusalemme. Aspetti archeologici dalle origini al periodo crociato. Parte II, Tavole: con annotazioni in italiano e in inglese. Jerusalem: Franciscan Printing Press Publ., 1981, pl. 41.

[14] C. Katsimbinis, The Uncovering of the Eastern Side of the Hill of Calvary and Its Base: New Lay-out of the Area of the Canons' Refectory by the Greek Orthodox Patriarchate. Liber Annuus, 1977, vol. 27, pl. C.

[15] V. C. Corbo, pl. 41.

[16] Ch. Coüasnon, p. 13.

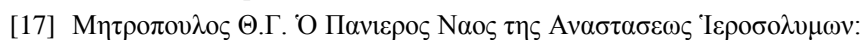

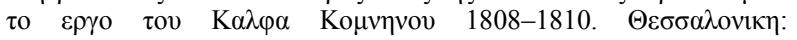

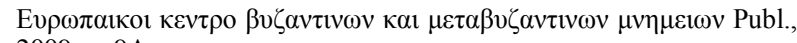
2009, p. 9A.

[18] D.V. Ainalov, Byzantine monuments of Athos. Byzantina Xponika, 1899, vol. VI, no. 1-2, p. 66 